\title{
Exocrine and Endocrine Pancreatic Cancer Clinical Distant Metastasis TNM Finding v7
}

National Cancer Institute

\section{Source}

National Cancer Institute. Exocrine and Endocrine Pancreatic Cancer Clinical Distant

Metastasis TNM Finding v7. NCI Thesaurus. Code C90302.

A clinical finding about one or more characteristics of exocrine or endocrine pancreatic cancer, following the rules of the TNM AJCC v7 classification system as they pertain to distant metastases. 